\title{
Beriberi Heart Disease in London
}

\author{
EDWARD BYRNE-QUINN,* B.A., M.B., M.R.C.P. ; CH. FESSAS, † M.D.
}

Cummary : Haemodynamic measurements before and after treatment are described in two patients with beriberi heart disease. The first patient had severe disease with a cardiac output of $17 \cdot 3$ litres per minute, which had returned to normal a month later. The second patient had moderate disease with a cardiac output of 7.4 litres per minute; a fall in this and a rise in systemic vascular resistance was found one and two hours after the intravenous injection of aneurine hydrochloride. The plasma pyruvate concentration was raised in the first patient but only slightly so in the second, in whom the pyruvate metabolism test was abnormal. The haemodynamic studies in both cases were of considerable help in making the diagnosis. The diagnosis of beriberi should be considered in any patient with heart disease who has a history of alcoholism, especially as prompt vitamin treatment is curative.

\section{Introduction}

Beriberi heart disease is a rare condition, and haemodynamic measurements have not been reported in this country, except that Sharpey-Schafer (1961), in his Oliver Sharpey lecture on venous tone, mentioned a case with a cardiac output of 15 litres per minute. Because the disease may be more prevalent than the above suggests, especially in patients with clinical evidence of heart failure and a history of alcoholism, haemodynamic measurements before and after treatment are here reported in two such patients seen within a year. In addition the acute effects of intravenous aneurine hydrochloride were studied in the second patient.

In the United States, Wagner (1965) tabulated the 13 cases in which haemodynamic measurements were made in that country. Similarly, Blacket and Palmer (1960) reported 16 cases from Australia, and Brink et al. (1966) two cases from South Africa. In the majority of these cases studies were carried out before and after treatment.

\section{Case 1}

A 39-year-old quantity surveyor living in Chelsea was admitted to hospital in December 1966 with a history of six months' intermittent ankle-swelling and dyspnoea on exertion together with cramp-like pains in the calves. Three weeks before admission he had developed sudden severe dyspnoea followed by increasing ankle oedema. He stated that he was separated from his wife, lived in a bed-sitting room, and had existed for the past six months mainly on 10 to 12 pints (5.7 to 6.8 litres) of draught beer a day. His meals were very infrequent, consisting of occasional rice dishes at Chinese restaurants. He did not complain of any cough, haemoptysis, or chest pain, but had gained $10.5 \mathrm{~kg}$. in weight in a month.

On examination he was in severe right-sided heart failure, with gross oedema of the legs and moderate bilateral calf tenderness. Homans's sign was negative. The jugular venous pressure was raised to the ears, and there was a loud right ventricular fourth heart sound (Fig. 1). The second sound varied nommally. Initially

- Registrar, Cardiac Department, St. Thomas's Hospital, London S.E.1. Present address: Cardiovascular Pulmonary Research Laboratory, University of Colorado Medical Center, 4200 East Ninth Avenue, Denver, Colorado 80220, U.S.A.

t Registrar, Cardiac Department, St. Thomas's Hospital, London S.E.1. Present address: Nicosia General Hospital, Nicosia, Cyprus. the extremities were cold and sweating, later becoming warm when he was settled in the ward, and it was then obvious that the pulse was bounding at $100 /$ minute. Blood pressure was $110 / 60 \mathrm{~mm}$. $\mathrm{Hg}$. There were scattered rhonchi in the chest, and the liver was enlarged $2 \mathrm{~cm}$. below the costal margin but was not pulsatile; there was minimal ascites. The central nervous system was intact and there was no evidence of peripheral neuritis.

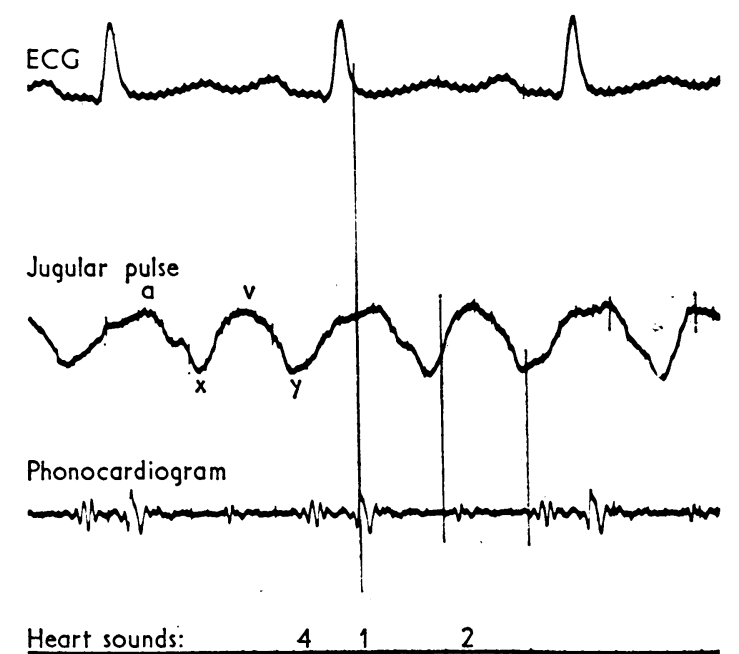

FIG. 1.-Case 1. Phonocardiogram showing loud fourth heart sound.

Haemodynamic Data.-These were obtained on admission and four weeks after treatment. Right heart catheterization was performed with fine nylon catheters (Bradley, 1964). Brachial artery catheterization was done by the Seldinger (1953) teohnique. Pressures in the right atrium, pulmonary artery, and brachial artery were measured by Statham P23Db transducers. Cardiac output was measured by the Fick principle. On admission the measurements confirmed severe right-sided heart failure (Table I).

TABle I.-Case 1. Haemodynamic Data on Admission and One Month TABLE 1.-Case 1. Haemodynamic Data on
After Treatment

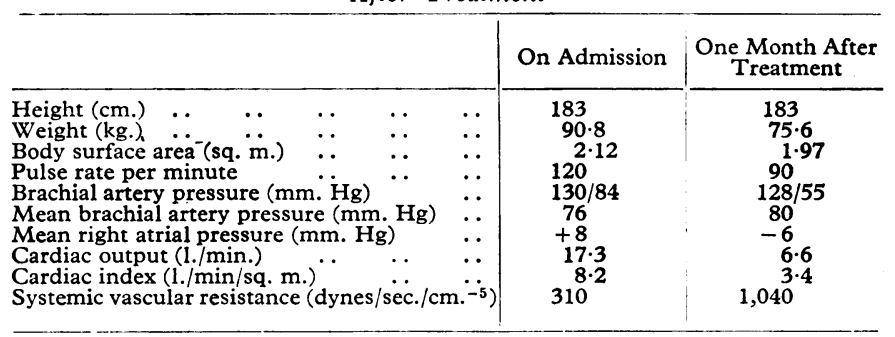

Other Investigations.-Serum pyruvate was raised to $3.1 \mathrm{mg} . /$ $100 \mathrm{ml}$. on admission; four weeks after treatment it had fallen to $0.8 \mathrm{mg} . / 100 \mathrm{ml}$. Chest $x$-ray examination on admission showed an enlarged heart and increased pulmonary vascularity; this had returned to normal six weeks later (Fig. 2). The electrocardiogram, apart from sinus tachycardia, was normal. Haemoglobin $15.2 \mathrm{~g} . /$ $100 \mathrm{ml}$. (104\%); W.B.C. $6,500 / \mathrm{cu}$. cm., with a normal differential ; E.S.R. $1 \mathrm{~mm}$./hour ; serum sodium $132 \mathrm{mEq} / 1$., potassium $3.8 \mathrm{mEq} / \mathrm{l}$., bicarbonate $23 \mathrm{mEq} / \mathrm{l}$, urea $14 \mathrm{mg} . / 100 \mathrm{ml}$., bilirubin $1.5 \mathrm{mg} . / 100 \mathrm{ml}$., alkaline phosphatase 9 K.A. units. Plasma proteins: total $5.4 \mathrm{~g} . / 100 \mathrm{ml}$. (albumin $3.8 \mathrm{~g}$., globulin $1.6 \mathrm{~g}$.), with normal electrophoresis. Bromsulphalein retention was normal. 


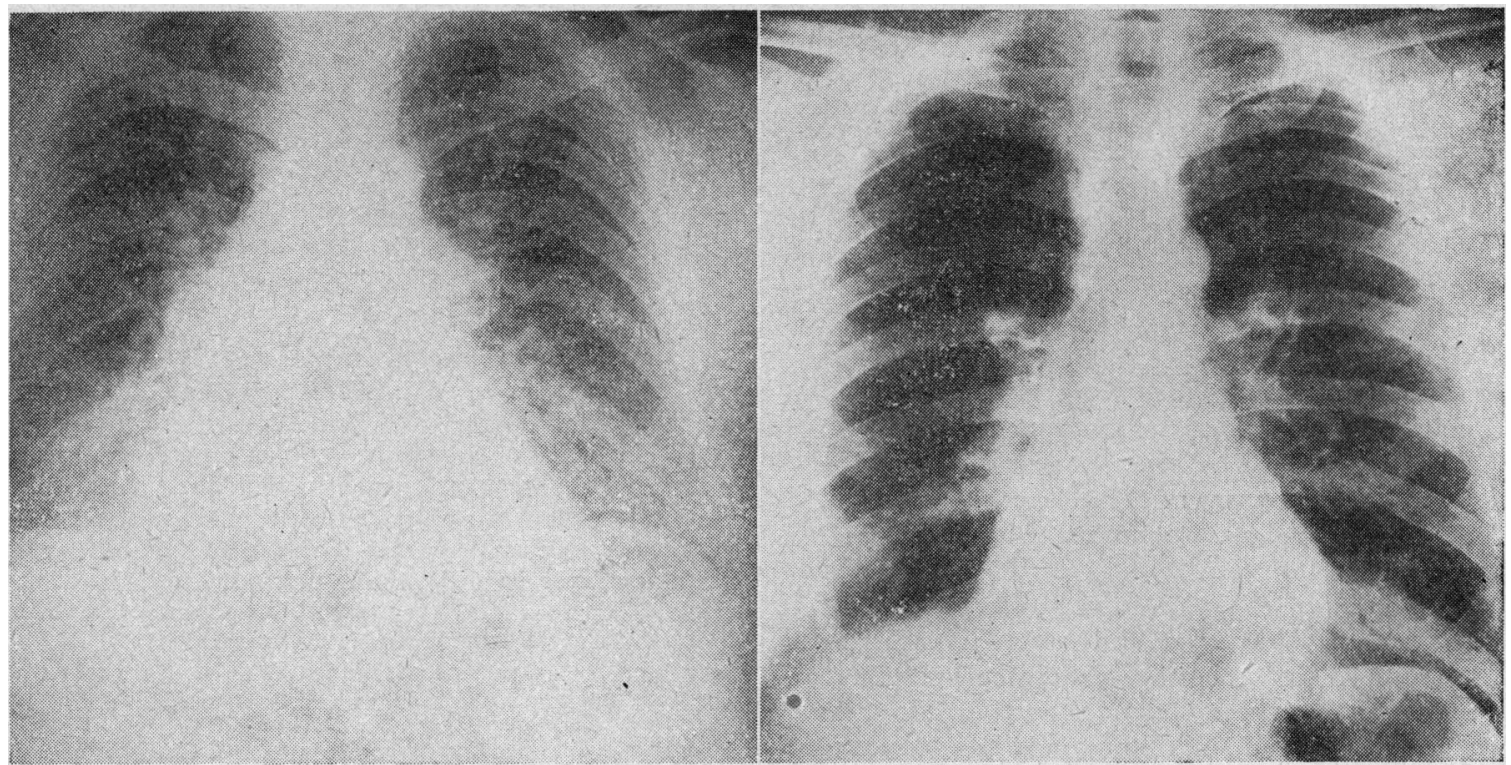

FIG. 2.-Case 1. Radiograph before treatment (left) and six weeks after treatment (right).

Liver biopsy showed normal liver architecture with some periportal fibrosis. The parenchymal cells showed a moderate degree of fatty change, and there was no alcoholic hyaline present or evidence of cirrhosis.

Treatment and Course.-Treatment consisted of bed rest and a normal diet. In addition parenteral aneurine hydrochloride $200 \mathrm{mg}$. was given for the first three days. During this period he had an evening pyrexia up to $100.4^{\circ} \mathrm{F}$. $\left(38^{\circ} \mathrm{C}\right.$.). A brisk diuresis began on the fourth day; at this time, however, he developed delinium tremens, and other vitamins in the form of Parentrovite were therefore added; he also required large doses of chlorpromazine. Thereafter he improved steadily, his ultimate weight loss being $15.2 \mathrm{~kg}$. (Fig. 3). When seen as an outpatient six months later he was well but still had a soft fourth heart sound.

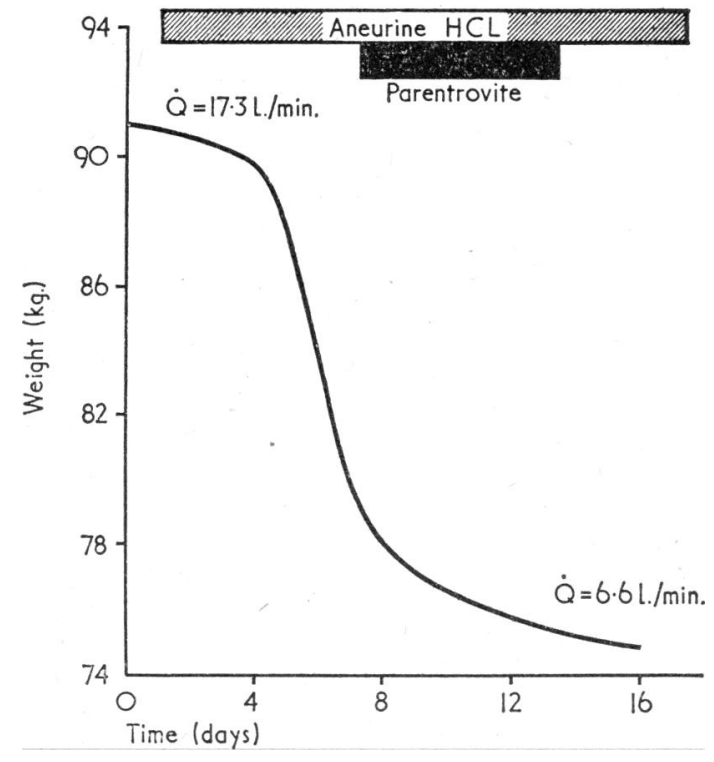

FIG. 3.-Case 1. Response to treatment.

\section{Case 2}

A 43-year-old wire-rope worker living in S.W. London was admitted to hospital in November 1967 with a nine-month history of shortness of breath on exertion with no orthopnea and no paroxysmal nocturnal dyspnoea, and a six-month history of ankle swelling. He was dyspnoeic when walking quickly on the flat, and had been off work three weeks because this was getting worse. $\mathrm{He}$ had had oocasional palpitations. He had had no pain in limbs or chest. He admitted to being a heavy beer drinker-anything from 8 to 20 pints $(4 \cdot 6$ to $11 \cdot 4$ litres) a day-and that this had been very heavy for the past year owing to matrimonial troubles culminating in divorce. He, however, insisted that he always had one cooked meal a day but ate very little else.

On examination he was anxious and depressed. His hands were warm and dry and he had a pronounced coarse tremor of his outstretched hand, and there was also a tremor of his tongue. His pulse was $116 / \mathrm{min}$, bounding, B.P. 110/60. Jugular venous pressure was not raised. The apex beat was in the fifth intercostal space but displaced into the anterior axillary line. There was a right ventricular fourth heart sound and a normally varying second sound. The chest was clear and there was no oedema. The liver was enlarged $4 \mathrm{~cm}$. below the costal margin and was soft, not tender, and not pulsatile. In the central nervous system he had some nystagmus on gaze to the left and evidence of peripheral neuritis, with absent ankle jerks and diminished knee jerks but with no sensory loss. Psychiatrically it was considered that there was no impairment of mental ability. His history suggested that he had had episodes of cardiac failure, but apart from his gallop he appeared to be compensated on admission. Beriberi seemed to be a likely diagnosis.

Haemodynamic Data.-These were obtained on admission and four weeks after treatment. The techniques used were the same as for Case 1 except that cardiac output was measured by the thermodilution technique (Branthwaite and Bradley, 1968). In addition the effect of acute intravenous injection of aneurine hydrochloride $200 \mathrm{mg}$. was studied on both occasions (Table II).

TABLE II.-Case 2. Haemodynamic Data Before and After Intravenous Aneurine Hydrochloride at Time of Admission and One Month After Treatment

\begin{tabular}{|c|c|c|c|c|c|c|}
\hline & \multicolumn{3}{|c|}{ On Admission } & \multicolumn{3}{|c|}{ One Month after Treatmen } \\
\hline & \multirow[t]{2}{*}{ Control } & \multicolumn{2}{|c|}{$\begin{array}{c}\text { After Intravenous } \\
\text { Aneurine } \\
\text { Hydrochloride } \\
200 \text { mg. } \\
\end{array}$} & \multirow[t]{2}{*}{ Control } & \multicolumn{2}{|c|}{$\begin{array}{c}\text { After Intravenous } \\
\text { Aneurine } \\
\text { Hydrochloride } \\
200 \mathrm{mg} \text {. }\end{array}$} \\
\hline & & 1 Hour & 2 Hours & & 1 Hour & 2 Hours \\
\hline $\begin{array}{ll}\text { Height }(\mathrm{cm} .) & \\
\text { Weight }(\mathrm{kg} .) & \ldots\end{array}$ & $\begin{array}{c}165 \\
65 \cdot 2\end{array}$ & & & $\begin{array}{l}165 \\
62 \cdot 7\end{array}$ & & \\
\hline $\begin{array}{l}\text { Body surface area (sq. } \\
\text { m.) } \ldots \\
\text { Pulse rate per minute } \ldots\end{array}$ & $90^{1 \cdot 72}$ & 70 & 66 & $84^{1 \cdot 68}$ & 80 & 80 \\
\hline $\begin{array}{l}\text { Brachial artery pressure } \\
\text { (mm. Hg) } \\
\text { Mean brachial artery }\end{array}$ & $148 / 60$ & $190 / 83$ & $205 / 77$ & $157 / 80$ & $147 / 75$ & $147 / 73$ \\
\hline $\begin{array}{c}\text { pressure (mm. Hg) } \\
\text { Mean right atrial pres- }\end{array}$ & 88 & 113 & 111 & 110 & 103 & 100 \\
\hline $\begin{array}{l}\text { pressure (mm. Hg) } \\
\text { Cardiac output }(1 . / \mathrm{min} .) \\
\text { Cardiac index }(1 . / \mathrm{min} . /\end{array}$ & $\begin{array}{l}-3 \\
7 \cdot 4\end{array}$ & $\begin{array}{l}-1 \\
6 \cdot 2\end{array}$ & $\begin{array}{l}-2 \\
5 \cdot 4\end{array}$ & $\begin{array}{l}-5 \\
4 \cdot 2\end{array}$ & $\begin{array}{c}-3 \\
5 \cdot 5\end{array}$ & $\begin{array}{r}-6 \\
4 \cdot 9\end{array}$ \\
\hline $\begin{array}{l}\text { 8q. m.) } \\
\text { Systemic vascular resis- }\end{array}$ & $4 \cdot 3$ & $3 \cdot 6$ & $3 \cdot 1$ & 2.5 & $3 \cdot 3$ & $2 \cdot 9$ \\
\hline $\begin{array}{lll}\text { cm. } & -5) & \ldots\end{array}$ & 980 & 1,470 & 1,670 & 2,190 & 1,540 & 1,730 \\
\hline
\end{tabular}


Other Investigations.-A pyruvate metabolism test was abnormal before treatment but was within normal limits one month later (Table III). Chest $x$-ray examination showed moderate cardiac enlargement, which had returned to normal one month later (Fig. 4). The electrocardiogram was normal. Haemoglobin $15.9 \mathrm{~g} . / 100 \mathrm{ml}$. $(109 \%)$; W.B.C. $6,600 / \mathrm{cu}$. cm., with a normal differential ; B.S.R $4 \mathrm{~mm} . / 1$ hour ; serum sodium $136 \mathrm{mEq} / 1$., potassium $4.3 \mathrm{mEq} / 1$., bicarbonate $20 \mathrm{mEq} / \mathrm{l}$, urea $11 \mathrm{mg} . / 100 \mathrm{ml}$., bilirubin $1.5 \mathrm{mg}$./ $100 \mathrm{ml}$., alkaline phosphatase K.A. 15 units, S.G.O.T. 14 units. Plasma proteins; total $6.4 \mathrm{~g} . / 100 \mathrm{ml}$. (albumin $4.6 \mathrm{~g}$. globulin $1.8 \mathrm{~g}$.), with normal electrophoresis. Bromsulphalein retention was normal. The electroencephalogram was normal.

TABle III.-Case 2. Pyruvate Metabolism Test Before and After Treatment

\begin{tabular}{|c|c|c|c|c|c|}
\hline & & & \multicolumn{3}{|c|}{ Plasma Pyruvate (mg./100ml.) } \\
\hline & & & Before Treatment & After Treatment & Normal Range* \\
\hline $\begin{array}{l}\text { Fasting ... } \\
60 \text { minutes } \\
90 \text { minutes }\end{array}$ & $\because$ & $\because$. & $\begin{array}{l}1 \cdot 3 \\
2 \cdot 1 \\
2 \cdot 0\end{array}$ & $\begin{array}{l}0.9 \\
1.0 \\
1.2\end{array}$ & $\begin{array}{l}0.76 \pm 0.18 \\
0.92 \pm 0.17 \\
0.94 \pm 0.20\end{array}$ \\
\hline
\end{tabular}

$50 \mathrm{~g}$. of glucose given at 0 and 30 minutes.

* Joiner et al. (1950).

Treatment and Course.-Treatment consisted of bed rest, normal diet, and supplements of aneurine hydrochloride. He made a rapid and uneventful recovery and his weight fell from $65 \cdot 2$ to $62.7 \mathrm{~kg}$.

\section{Discussion}

The cardiac effects of beriberi were originally described by Oriental physicians at the beginning of this century. Aalsmeer and Wenckebach (1929) studied the disease in Java, and it was brought to the attention of physicians in this country by Wenckebach (1928) in his St. Cyres lecture. Keefer (1930) similarly studied the disease in China, and drew attention to it in the United States. These authors reported that the acute cardiac failure responded rapidly to treatment with pure vita$\min B_{1}$, and both they and Hashimoto (1937) were aware of fulminating cases in which death ensued within 24 to 48 hours, and this has occurred in this country (Wood, 1939).

The swift circulation time with generalized arteriolar dilatation had been observed before the era of cardiac catheterization (Kepler, 1925 ; Weiss and Wilkins, 1937 ; Wood, 1939). The first haemodynamic measurements were made by Burwell and Dexter (1947), and other reports from abroad have confirmed the high cardiac output with a low systemic vascular resistance returning to normal after treatment (Campbell et al., 1951; Lahey et al., 1953 ; Iseri et al., 1954 ; Olson, 1958 ; Lessard et al., 1959 ; Blacket and Palmer, 1960 ; Wagner, 1965 ; Brink et al.; 1966).

The two cases described here presented different problems. The first case had had symptoms suggestive of cardiac failure which were intermittent for six months before his admission with gross oedema and raised central venous pressure, the cardiac output being very high and the systemic vascular resistance being very low. There was dramatic improvement in his cardiac state with bed rest, normal diet, and aneurine hydrochloride treatment alone, confirmed by normal haemodynamic measurements a month later. His course, however, was complicated by delirium tremens, which responded to multiple vitamins and chlorpromazine. It would be wiser to treat such severe cases, who probably have other vitamin deficiencies as well, with multiple vitamins from the beginning. The fever that occurred with the starting of treatment has been observed previously (Weiss and Wilkins, 1937).

The second case was suspected of having beriberi from the history but did not have signs of heart failure on examination, though there was evidence of neurological involvement. Lahey et al. (1953) showed in their case a significant fall in cardiac output and a rise in systemic vascular resistance two hours after intravenous aneurine hydrochloride. Therefore this second patient was studied similarly, and we found a definite decrease in cardiac output and an increase in systemic vascular at one and two hours after the vitamin. This study was of particular help in confirming the diagnosis, as the control cardiac output was only moderately raised. There was in addition a definite rise in blood pressure after the vitamin, suggesting that peripheral arteriolar vasoconstriction was present. This was not observed by Lahey et al. (1953), but has been noted by others (Weiss and Wilkins, 1937 ; Porter and Downs, 1942). The patient served as his own control a month later when the identical procedure was repeated and showed no definite changes.

Biochemically, aneurine is necessary for the decarboxylation of pyruvic acid, which is the opening step of the reactions that feed into the citric acid cycle. Thus in severe beriberi there is a raised plasma pyruvate level as in Case 1. In less severe cases, however, the fasting plasma pyruvate may be normal (Platt, 1958 ; Olson, 1958). In Case 2 the fasting serum pyruvate was only slightly raised, but the pyruvate metabolism test (Joiner et al., 1950) was abnormal. One month later this test was repeated and was normal. In suspected cases in which there is a normal fasting pyruvate it is necessary to do a pyruvate metabolism test.

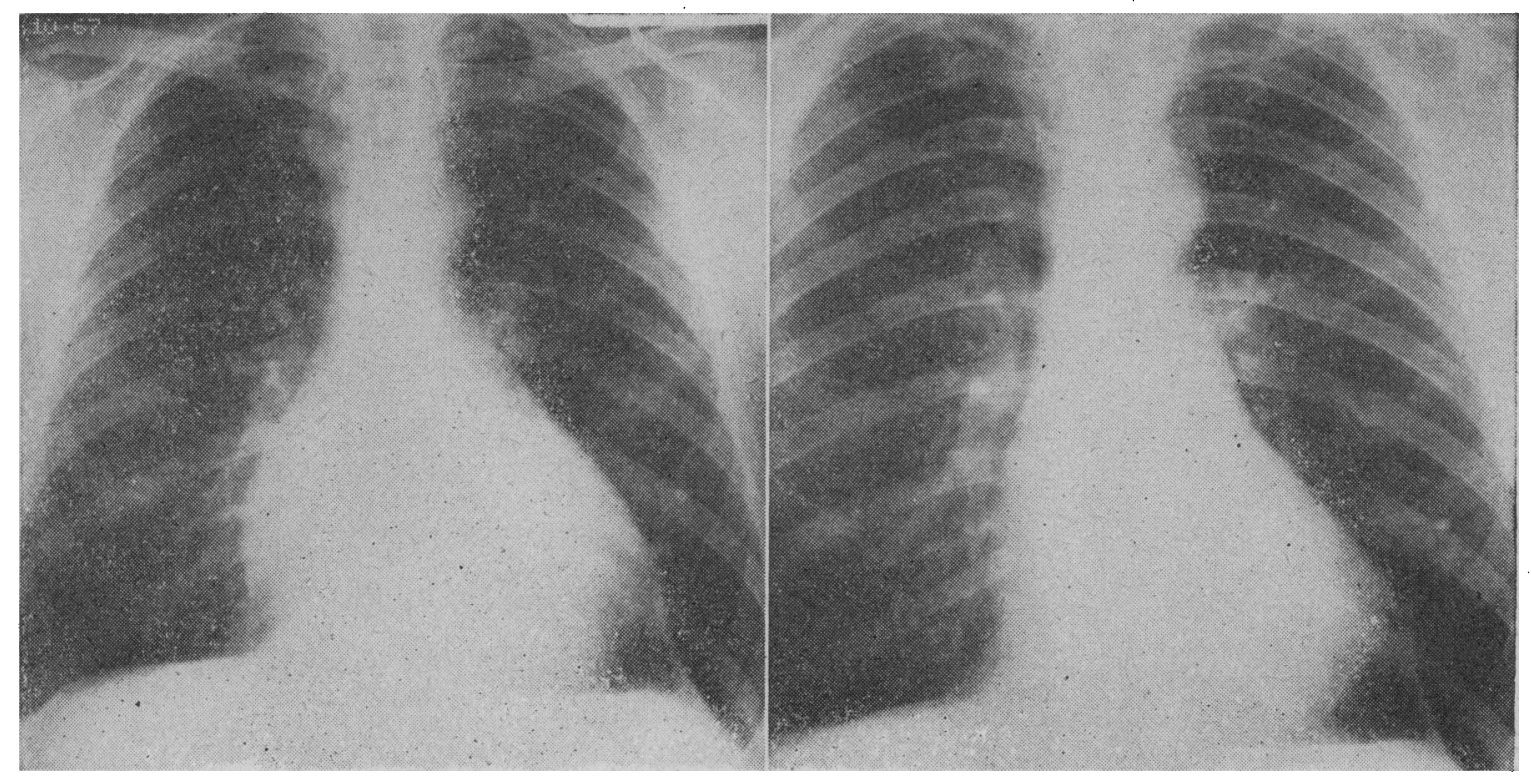

FIG. 4.-Case 2. Radiograph before treatment (left) and one month after treatment (right). 
The mechanism of the high cardiac output is thought to be due to lowering of the systemic vascular resistance, analogous to an arteriovenous fistula. Sharpey-Schafer (1961) studied forearm dynamics in two patients, one of whom had a cardiac output of 15 litres per minute. He showed that while there was a formidable dilatation of peripheral arteries the veins were constricted. He suggested that the high central venous pressure was not due to heart failure, as the Valsalva manœuvre showed that the heart was capable not only of reducing its stroke volume when the high filling pressure was reduced but of increasing it during the "overshoot" as in the normal subject, but that it was due to peripheral vasoconstriction in the presence of an increase in blood volume. Therefore, as well as peripheral arteriolar vasodilatation increasing the cardiac output, further driving of the heart would appear to occur because of the high filling pressure due to peripheral venoconstriction. However, in congestive heart failure per se there is peripheral venoconstriction (Wood et al., 1956).

In conclusion vitamin- $\mathrm{B}_{1}$ deficiency as a cause of cardiovascular disturbance may be rare in this country, but its recognition is important because it is amenable to treatment (Wood, 1939). Haemodynamic and pyruvate metabolism studies are shown here to be extremely valuable in making the diagnosis.

We would like to thank Dr. Evan Jones and Dr. Raymond Daley for allowing us to study patients under their care, and Dr. R. D. Bradley and Dr. M. A. Branthwaite for their help and advice.
REFERENCES

Aalsmeer, W. C., and Wenckebach, K. F. (1929). Wiener Archiv für innere Medizin, 16, 193.

Blacket, R. B., and Palmer, A. J. (1960). British Heart fournal, 22, 483. Bradley, R. D. (1964). Lancet, 2, 941.

Branthwaite, M. A., and Bradley, R. D. (1968). Fournal of Applied Physiology, 24, 434.

Brink, A. J., Lochner, A., and Lewis, C. M. (1966). South African Medical fournal, 40, 581.

Burwell, C. S., and Dexter, L. (1947). Transactions of the Association of American Physicians, 60, 59

Campbell, J. A., Selverstone, L. A., and Donovan, D. L. (1951). Fournal of Clinical Investigation, 30, 632.

Hashimoto, H. (1937). American Heart fournal, 13, 580.

Iseri, L. T., Uhl, H. S. M., Chandler, D. E., Boyle, A. J., and Myers, G. B. (1954). Circulation, 9, 247. Joiner, C. L., McArdle, B., and Thompson, R. H. S. (1950). Brain,

Keefer, C. S. (1930). Archives of Internal Medicine, 45, 1.

Kepler, E. J. (1925). Fournal of the American Medical Association, 85, 409.

Lahey, W. J., Arst, D. B., Silver, M., Kleeman, C. R., and Kunkel, P. (1953). American fournal of Medicine, 14, 248.

Lessard, R., Bernier, J. P., and Morin, Y. (1959). Canadian Medical Association fournal, 80, 112 .

Olson, R. E. (1958). Federation Proceedings, 17, Suppl. No. 2, p. 27. Platt, B. F. (1958). Federation Proceedings, 17, Suppl. No. 2, p. 13. Porter, R. R., and Downs, R. S. (1942). Annals of Internal Medicine, 17,645 .

Seldinger, S. I. (1953). Acta Radiologica, 39, 368.

Sharpey-Schafer, E. P. (1961). British Medical fournal, 2, 1589.

Wagner, P. I. (1965). American Heart fournal, 69, 200.

Weiss, S., and Wilkins, R. W. (1937). Annals of Internal Medicine, 11, 104.

Wood, P. (1939). Proceedings of the Royal Society of Medicine, 32, 817.

Wood, J. E., Litter, J., and Wilkins, R. W. (1956). Circulation, 13, 524.

\section{Medical Memoranda}

\section{Liver Transplantation in Man after an Extended Period of Preservation by a Simple Technique}

British Medical fournal, 1969, 4, 28-30

Satisfactory function in a liver transplant is dependent on the availability of a homograft in which anoxic damage has been kept to a minimum. Ischaemic injury may be manifest by the development of uncontrollable bleeding during transplantation or progressive liver failure in the event of survival from operation. Since infusion of cold electrolyte solutions had hitherto provided only two hours of tolerable ischaemia, various complex methods of preservation have been evaluated experimentally (Marchioro et al., 1963 ; Mikaeloff et al., 1965) and tried clinically (Starzl et al., 1963) in attempts to provide organs of good quality for transplantation. Utilizing low-flow perfusion with diluted blood, hypothermia at $4^{\circ} \mathrm{C}$., and hyperbaric oxygenation, Brettschneider et al. (1967) obtained satisfactory function after 10 to 15 hours' preservation in dogs. This was the first successful ex-vivo perfusion system and was employed by Starzl et al. (1968) in seven patients, in all of whom good initial function was obtained.

These methods of providing a liver of good quality are complex, however, and may be difficult to organize. Recent reports have suggested that good liver function may still be obtained when the organ is removed after cessation of heart beat, provided it is cooled by infusion beginning within 15 minutes of

* Preservation fluid containing $400 \mathrm{ml}$. of reconstituted human plasma, $10 \mathrm{ml}$. of $2 \%$ procaine, $8 \mathrm{ml}$. of $5 \%$ glucose, and $20 \mathrm{ml}$. of $1.4 \%$ sodium bicarbonate (Calne and Williams, 1968). death (Calne and Williams, 1968 ; Schalm, 1968). This report confirms the value of simple cooling by infusion and indicates, moreover, that satisfactory function may still be obtained after preservation for as long as five hours.

\section{CASE Report}

A 52-year-old man was admitted to the Manchester Royal Infirmary on 3 January 1969 with painless obstructive jaundice of recent onset. On examination there were no abnormal physical signs apart from jaundice.

Laboratory Investigations.- $\mathrm{Hb} 92 \%$, white blood count and differential normal, platelets $260,000 / \mathrm{cu}$. mm. Serum albumin $4.3 \mathrm{~g}$., globulin $2.9 \mathrm{~g}$., bilirubin $14.8 \mathrm{mg} . / 100 \mathrm{ml}$., thymol turbidity 0.6 unit, alkaline phosphatase 29 K.A. units $/ 100 \mathrm{ml}$., serum aspartate aminotransferase 40 units/ml., serum alanine aminotransferase 85 units $/ \mathrm{ml}$. Blood sugar $125 \mathrm{mg} . / 100 \mathrm{ml}$., blood urea and electrolytes normal. Prothrombin time one-stage (Quick) 13.5 seconds, fibrinogen $425 \mathrm{mg} . / 100 \mathrm{ml}$. Coagulation studies did not show any abnormality. A chest $x$-ray film was normal but a barium meal revealed a deformed duodenal cap. A transhepatic cholangiogram showed gross dilatation of the intrahepatic bile ducts with complete obstruction at the porta hepatis.

At laparotomy on 10 January an intrahepatic mass was palpable above the porta hepatis, with collapse of the extrahepatic biliary system. Choledochostomy, with the object of probing the hepatic ducts and possible biopsy of a presumed bile duct carcinoma, was unsuccessful. As a result of these findings, and in the presence of deepening jaundice, the patient was referred for consideration of a transplant.

Liver Transplantation.-Transplantation was undertaken on 22 January when a donor liver became available. Both donor and recipient were $\mathrm{O}$ positive blood group. On lymphocyte (tissue) typing there were two major and two minor incompatibilities and no pre-existing cytotoxic antibodies were detected. 